\title{
Natural and artificial secondary contact in brown trout (Salmo trutta, L.) in the French western Pyrenees assessed by allozymes and microsatellites
}

\author{
D Aurelle ${ }^{1}$, G Cattaneo-Berrebi ${ }^{1,2}$ and P Berrebi ${ }^{1,2}$ \\ ${ }^{1}$ Laboratoire Génome, Populations et Interactions, CNRS UMR 5000, cc063, Université Montpellier 2, place E. Bataillon, 34095 \\ Montpellier, cedex 05, France
}

\begin{abstract}
Analysis of allozyme polymorphism in brown trout (Salmo trutta) populations from south-western France shows that two genetically differentiated wild forms (characterised by the $\mathrm{LDH}-\mathrm{C} 1^{*} 100$ and 90 alleles) introgress in this area. As allozymes could not evaluate the impact of stocking in the Atlantic basin, microsatellites have been necessary to detect the influence of hatchery fish and to confirm that the observed structure was natural. Microsatellites confirm the distinctness of the two wild forms based on allozyme loci. This situation provides a new example of secondary contact
\end{abstract}

for this species in the Atlantic basin, with various levels of mixing being seen between the two population groups. The origin of these forms is discussed in the light of previous studies concerning modern and ancestral Atlantic trout (Hamilton et al, 1989) and lineages stemming from different glacial refuges (Garcia Marin et al, 1999; Weiss et al, 2000). This local analysis provides new insights in defining the evolutionary history of this species and confirms the important role of glaciation events in this history.

Heredity (2002) 89, 171-183. doi:10.1038/sj.hdy.6800120

Keywords: Salmo trutta; allozymes; microsatellites; population genetics; stocking; correspondence analysis; assignment

\section{Introduction}

Freshwater fish occur in island-like habitats, and the present and historical connections among rivers are therefore the basis of the interpretation of the observed genetic relationships among populations. Thus these populations constitute good models for analysing the consequences of the most recent glaciation events, which have influenced the genetic structure of various kinds of species (Hewitt, 1996; Taberlet et al, 1998). Among freshwater fish, several examples of differentiated lineages stemming from different refuges have already been studied (Bernatchez and Dodson, 1991; Mandrak and Crossma, 1992; Bernatchez and Wilson, 1998; Durand et al, 1999). Such differentiated entities can come into secondary contact during recolonisation, as shown by several examples (Persat and Berrebi, 1990; Dowling and Hoeh, 1991). These situations are interesting for studying the genetic consequences of long-term isolation: do they lead to complete mixing, reproductive isolation, or hybrid zones? Local studies of genetic structure can then provide useful complementary information to large-scale phylogeographic approaches.

The brown trout (Salmo trutta, L.), which has a wide

Correspondence: P Berrebi, Laboratoire Ecosystèmes Lagunaires, CNRS UMR 5119, cc093, Université Montpellier 2, place E. Bataillon, 34095 Montpellier, cedex 05, France. E-mail: berrebi@crit.univ-montp2.fr

${ }^{2}$ Present address: Laboratoire Ecosystèmes Lagunaires, CNRS ERS 2011, cc093, Université Montpellier 2, place E. Bataillon, 34095 Montpellier, cedex 05, France

Received 19 September 2001; accepted 23 April 2001 area of distribution, has been strongly influenced by the most recent glaciation events. Northern Europe was covered by ice sheets and must have been only recently recolonised by freshwater fish: for example the ice did not retreat from Scotland and most of Scandinavia until about 10000 years BP (Hamilton et al, 1989). As brown trout populations are usually highly polymorphic (Guyomard, 1989; Ferguson et al, 1995; Estoup et al, 1998), the more or less long-term isolation due to glaciations could have created genetically differentiated entities which could have come into secondary contact during recolonisation.

It is now clearly established that among European brown trout populations, five major groups can be distinguished: Adriatic, Atlantic, Danubian, Marble and Mediterranean (Bernatchez et al, 1992; Bernatchez, 2001). Among Atlantic populations, several subgroups have also been proposed. Using the distribution of the different alleles of the $\mathrm{LDH}-\mathrm{C} 1^{*}$ locus, Ferguson and Fleming (1983) and Hamilton et al (1989) concluded that two races were present in northern Europe: an ancestral one (possessing the $\mathrm{LDH}-\mathrm{C}{ }^{*} 100$ allele and which would have first recolonised this area) and a modern one (with LDH-C1*90, which would have replaced the ancestral one when possible). Nevertheless, Hynes et al (1996), using mtDNA, concluded that more than two colonisation events have occurred. More recently, Garcia-Marin et al (1999), using the distribution of $L D H-C 1 *$ alleles, proposed that these two population groups are the consequence of two glacial refuges. Weiss et al (2000), considering the genetic originality of Portuguese populations, reinterpreted these data and proposed a more geographi- 
cally limited postglacial dispersal of brown trout into northern Europe. More precisely, according to these authors, northern Atlantic populations have come from refugia located north of the Iberian Peninsula.

The rivers of the western French Pyrenees (Pyrénées Atlantiques) could contain both of these lineages. In a preliminary allozymic study (unpublished report), we observed that some populations had a high frequency of the LDH-C1*90 allele, while others were dominated by the 100 allele, and several samples possessed both alleles at significant frequencies. As the 90 allele predominates in populations located north of this region, and the 100 allele is fixed in southern wild populations (Iberian peninsula; Garcia-Marin et al, 1999), Pyrenean rivers could be a point where two genetically differentiated forms or lineages meet and interact. This constitutes a new and southern example of the interaction between low and high LDH-C1*100 frequency populations (lineages I and II according to the terminology of Garcia-Marin et al, 1999). It could thus help in understanding the phylogeography of brown trout in the Atlantic basin. Moreover it could be a good model for studying secondary contacts.

But there is a difficulty: stocking practices are very active in France and all river populations may be affected. Most of the hatchery samples belong to the Atlantic grouping (Guyomard, 1989; Hansen et al, 1995; Poteaux and Berrebi, 1997). These domestic forms, carrying the LDH-C1*90 allele, cannot be separated by allozymes from the wild trout of the same group. The use of more variable markers is thus necessary for this distinction: microsatellites appear suitable because of their high variability (Jarne and Lagoda, 1996). It is also instructive to ask whether the two types of independent markers, allozymes and microsatellites, show the same distinction between the two lineages. Moreover, several studies have shown that microsatellites could, in some cases, be more efficient than allozymes in discriminating some genetically close populations (Sanchez et al, 1996; Estoup et al, 1998).

A first study of the western French Pyrenees using only three microsatellite loci tended to show a distinction between low and high $\mathrm{LDH}-\mathrm{C} 1^{*} 90$ population groups (Aurelle and Berrebi, 1998). Wild and domestic fishes from the same group (high $\mathrm{LDH}-\mathrm{C} 1{ }^{* 90}$ ) were discriminated using Artificial Neural Networks using data from four microsatellite loci (Aurelle et al, 1999). For practical reasons we will now use the following nomenclature: Atlantic populations with high LDH-C1*90 frequency (lineage I for Garcia-Marin et al, 1999) will be designated as the '90group', and populations with low LDH-C1*90 and high LDH-C $1{ }^{*} 100$ frequencies (lineage II) will be named the '100group'. Populations with intermediate frequencies should at first be considered as mixed populations.

Here we used six microsatellite loci to determine if brown trout populations from this area consist of two phylogeographic lineages in secondary contact. As stocking is an important factor in the management of this species, we first tried to distinguish wild and domestic fish.

The investigation comprised two steps: (i) an analysis of 31 presumptive allozymic loci applied to a large sample (784 individuals) in order to give a general framework of genetic diversity in the region, and (ii) microsatellite analysis of a subset of samples (504) to discriminate the impact of stocking inside the 90-group, and to compare the 90 and 100-group populations.

\section{Materials and methods}

\section{Samples}

The samples are described in Table 1 and their locations are shown in Figure 1. No barriers to migration have been identified for the studied populations in the Adour, Untxin and Nivelle basins. Six hatchery samples were included as domestic references. The Aude basin (21) and the Ebro River (1) samples were added as Mediterranean references (Berrebi et al, 2000). The fish were caught by electrofishing and most individuals were killed for enzymatic studies. For each location, when possible, we sampled individuals of various sizes to prevent several individuals coming from the same family (Hansen et al, 1997). Using this method several cohorts were usually sampled (up to five main cohorts). Sampling was conducted over a river length of $100 \mathrm{~m}$.

Among these samples, only 12 were subjected to microsatellite analyses (see Table 1). To increase the efficiency of the discrimination, we re-sampled three stations (populations 16, 17 and 19) where more than 80 individuals were caught and released after fin clipping.

\section{Allozyme analysis}

Trout destined for allozyme analysis were anaesthetised in the field, and about $1 \mathrm{~g}$ each (when possible) of muscle, liver and the eyes were taken. These organs were immediately frozen in liquid nitrogen. Blood was first centrifuged and cells and serum frozen separately.

In the laboratory, homogenised tissues were subject to electrophoresis on horizontal starch gels. The staining methods were those of Pasteur et al (1987), as modified by Krieg (1984) and Beaudou (1993) for trout (see also Poteaux et al, 1998a). Fifteen enzymatic systems were encoded by 31 presumptive loci. It was not possible to characterise all the genotypes of $C K-A 1^{*}$ because of overlapping gel zones with $C K-2 *$. The allelic frequencies were then recalculated for $C K-A 1^{*}$ (underlined in the Appendix) from the frequency of the recognisable genotype (homozygote 125125) assuming Hardy-Weinberg equilibrium.

The hatchery samples 24 and 25 were analysed by Poteaux et al (1998a) for allozymes.

\section{Microsatellite analysis}

Six microsatellite loci were used. Strutta 58 was cloned by Poteaux et al (1999). The loci MST 73, 15, and 543 developed by Presa et al (1994) were obtained from brown trout, and are perfect or imperfect dinucleotide microsatellites. Ssa 171 and Ssa 197 were originally cloned in Atlantic salmon (Salmo salar) by O'Reilly et al (1996) and successfully amplified in brown trout. They consist of a compound microsatellite of $4 \mathrm{bp}$ and $2 \mathrm{bp}$ repeat motifs. DNA extraction, PCR protocols and microsatellite analysis were as described by Aurelle and Berrebi (1998).

\section{Statistical analysis}

Most population genetics statistics were computed using the GENETIX software (Belkhir et al, 1998). Genetic diversity within populations was evaluated by calculating observed and unbiased expected heterozygosity. F-statistics were evaluated using the estimators of Weir and Cockerham (1984), which can take into account variations 
Table 1 List of the samples (location on the map, Figure 1), sample size for both allozymes and microsatellite investigations, and percentage of the modern allele $L D H-C 1^{*}$.

\begin{tabular}{|c|c|c|c|c|c|c|c|}
\hline Number & Locality & River & Basin & & $\begin{array}{l}\text { Allozymes } \\
\text { sample size }\end{array}$ & $\begin{array}{c}\text { Microsatellites } \\
\text { sample sizes }\end{array}$ & $\begin{array}{l}\text { \% of } L D H- \\
\quad C 1 * 90\end{array}$ \\
\hline 1 & - & Harlondo & Ebre (Med.) & Sept93 & 22 & - & 2 \\
\hline 2 & Herboure & Andurentako & Untxin & Sept93 & 5 & 5 & 0 \\
\hline 3 & Sare & Beherekobentako & Nivelle & Sept93 & 24 & 24 & 0 \\
\hline 4 & Dancharia & Nivelle & Nivelle & Sept93 & 30 & 30 & 0 \\
\hline 5 & Bidarray & Bastan & Adour & Sept93 & 29 & 29 & 4 \\
\hline 6 & Béhérobie & Nive de Béhérobie & Adour & Sept93 & 30 & 25 & 27 \\
\hline 7 & Esterençuby & Esterenguibel & Adour & Sept93 & 30 & - & 40 \\
\hline 8 & - & Ilhounatzeko & Adour & Sept93 & 30 & - & 55 \\
\hline 9 & Cauteret & Marcadau & Adour & Sept92 & 30 & 15 & 33 \\
\hline 10 & stream & Aratille & Adour & Oct91 & 22 & - & 57 \\
\hline 11 & lake & Aratille & Adour & Oct91 & 34 & - & 75 \\
\hline 12 & Huas & Gaube & Adour & Sept92 & 30 & - & 22 \\
\hline 13 & Napoléon bridge & Gavarnie & Adour & July93 & 30 & - & 38 \\
\hline 14 & Lienz refuge & Glère & Adour & Sept92 & 30 & - & 57 \\
\hline 15 & dam & Gave Ossoue & Adour & Sept92 & 30 & - & 55 \\
\hline 16 & Bagnères de Bigorre & Oussouet & Adour & July93 & 30 & 86 & 82 \\
\hline 17 & Chiroulet & Adour de Lesponne & Adour & Sept92 & 30 & 86 & 89 \\
\hline 18 & Peyras bridge & Arrimoula & Adour & July93 & 30 & - & 88 \\
\hline 19 & Argeles & Luz & Adour & July93 & 30 & 88 & 95 \\
\hline 20 & Bulan & Arros & Adour & July93 & 29 & - & 96 \\
\hline 21 & - & Boutadiol & Aude (Med.) & Jun93 & 30 & - & 20 \\
\hline 22 & Cauteret & $\begin{array}{l}\text { hatchery } \\
\text { (Spanish strain) }\end{array}$ & - & Sept92 & 24 & - & 6 \\
\hline 23 & Cauteret & $\begin{array}{l}\text { hatchery } \\
\text { (Estaing strain) }\end{array}$ & - & Sept92 & 20 & - & 100 \\
\hline 24 & La Canourgue & hatchery & - & Sept91 & 32 & 50 & 95 \\
\hline 25 & Brassac & hatchery & - & Sept91 & 30 & 30 & 100 \\
\hline 26 & Suech & hatchery & - & Sept93 & 35 & 36 & 99 \\
\hline 27 & Fontanelle & hatchery & - & July94 & 30 & - & 97 \\
\hline
\end{tabular}

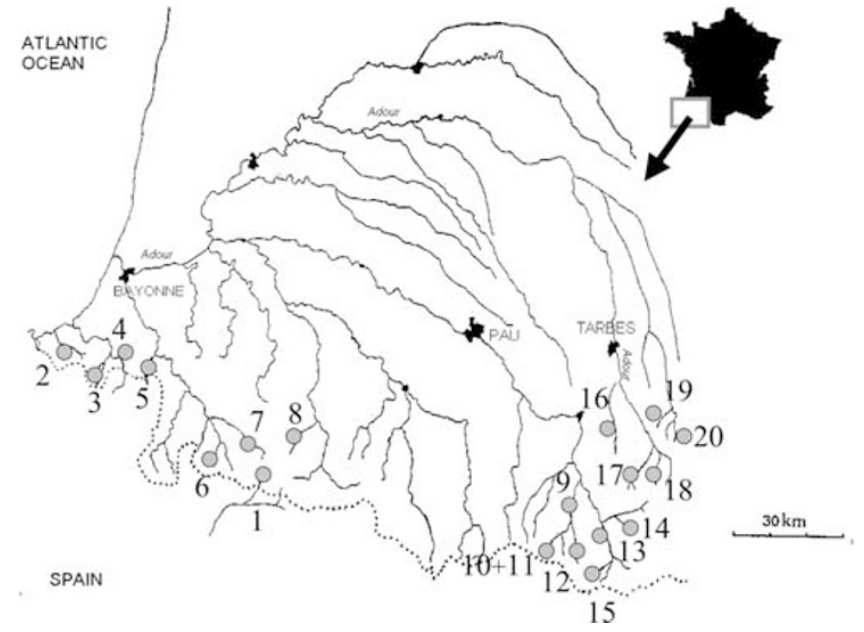

Figure 1 Geographical position of the brown trout populations studied.

in sample sizes. Linkage disequilibria were determined for all pairs of loci by the Linkdis algorithm (Black and Krafsur, 1985). To test the departures from HardyWeinberg equilibrium, permutations of alleles within each population were realised and the $F_{\mathrm{IS}}$ estimator ( $f$ ) calculated for each data set. This gave a distribution of the $F_{\mathrm{IS}}$ estimator under the null hypothesis (panmixia).
The $F_{\text {IS }}$ were considered significantly different from 0 at $P=0.05$ if less than $5 \%$ of the permutations gave a $F_{\mathrm{IS}}$ greater than or equal to the observed value. The existence of linkage disequilibria was tested by permuting monolocus genotypes among individuals in the same sample. The genetic differentiation between populations was tested by permuting individuals between samples and by computing $\theta$ ( $F_{\mathrm{ST}}$ estimator) for each permutation. All tests were conducted using GENETIX with 100 or 1000 permutations according to the test. Sequential Bonferroni corrections were performed for simultaneous multiple tests (Rice, 1989).

We also conducted correspondence analyses (CA) using GENETIX. In this kind of analysis, individuals are first coded according to the presence of the different alleles with values 0 (allele absent), 1 (heterozygote), 2 (homozygote for the allele). The computation then aims at finding composite axes which are a combination of the variables and which optimise the differences between the analysed individuals. The relationships among individuals can be visualised on two or three axes, and not just the relationships among populations (as in population trees). This technique is useful for analysing the genetic homogeneity of a given sample. This computation is not completely independent from differentiation parameters, as Guinand (1996) has shown that the inertia values (ie the proportion of the total information explained by an axis, given in percent) along each axis are equivalent to linear combinations of the monolocus $F_{\mathrm{ST}}$ values. 
Assignment tests were conducted to classify individuals among populations. The aim of this technique was to check the homogeneity of the different groups and to detect individuals which could have been the result of migration or stocking. For these tests we computed the probability of occurrence of each individual in the different populations. Briefly, each individual was added to the population tested. A correction was made depending on the size of the sample in which this individual was found: the individual's alleles were added with the frequencies $x /\left(2^{*} n\right)$ where $n$ is the sample size, and $x=0,1$ or 2 depending on the number of copies of the allele possessed by the individual. The probability of occurrence of the individual was then calculated using these new frequencies and assuming Hardy-Weinberg equilibrium. The individual was then assigned to the population where it had the highest probability. Computations were realised by using the Identity software developed by $\mathrm{K}$ Belkhir (unpublished). Loci with missing data for complete populations were not used in this analysis (this concerned the CK-3, SOD-2 MDH-3 and TF loci). It was not possible to test individuals using allozymes and microsatellites together as different individuals were analysed for each marker.

\section{Results}

\section{Allozymes}

Allelic frequencies: Thirty-one loci were analysed, of which 10 were monomorphic. Among the variable loci, the allelic frequencies of those having phylogeographic interest can be described more precisely (Appendix):

$L D H-C 1^{*}$ : two alleles 90 and 100, were present at very different frequencies depending on the populations. Some samples were fixed or almost fixed for LDH-C1*90 (hatcheries, except the Spanish strain 22, and populations 17, 19 and 20). Others showed high frequencies of LDHC1*100 (2 to 4, 22 and 1, which belongs to the Mediterranean basin). The $\mathrm{LDH}-\mathrm{C}^{*}{ }^{* 90}$ allele appeared to be much more frequent in the eastern part of the Adour basin than in the western part and in the Nivelle and the Untxin basins (where it is absent).

$T F^{*}$ : the 100 allele is characteristic of Atlantic populations (Poteaux et al, 1998a) and most populations in this region showed high frequencies for this allele. Nevertheless, the 102 allele, typical of Mediterranean populations, was also present, and not only as expected, in Mediterranean samples (sample 1, the Spanish domestic stock 22 and the Mediterranean control sample 21) but also in other samples such as 17 (with a frequency of 0.32 ).

Genetic variability within populations: Unbiased expected and observed heterozygosities $\left(\mathrm{H}_{\mathrm{nb}}\right.$ and $\left.\mathrm{H}_{\mathrm{o}}\right), F_{\mathrm{IS}}$ values and the associated probabilities are given in the Appendix. The expected heterozygosity values varied between 0.05 (sample 1) and $0.12(6,7,13)$. The genetic diversity of hatchery samples varied from 0.04 (Spanish strain, 22) to 0.10 (27). Among natural populations, the different rivers showed highly contrasting diversities. In terms of departures from the Hardy-Weinberg equilibrium, six samples $(1,3,4,6,9$ and 21) appeared to have a deficiency of heterozygotes that differed significantly from zero (1000 permutations and after Bonferroni correction).
For linkage disequilibria, 906 tests were performed (100 permutations each) and after a sequential Bonferroni correction, 14 remained significant. Apart from 21 with three significant results $\left(F B P-1^{*} / L D H-C 1^{*}, F B P-1^{*} / M P I^{*}, L D H-\right.$ $\left.C 1^{*} / M P I^{*}\right)$ and nine with two significant results $\left(A A T-1^{*}\right.$ $/ L D H-C 1^{*}$ and $\left.A A T-4^{*} / M D H-2^{*}\right)$, all other populations had only one or no apparent disequilibria. For sample 21 (Mediterranean basin), five homozygote individuals for the alleles LDH-C1*90 and FBP-1*100 were present (more frequent in the Atlantic basin), which were probably of recently stocked domestic origin (Berrebi et al, 2000).

Genetic differences among populations: The mean pairwise $F_{\mathrm{ST}}$ among all samples was 0.30 but when only Pyrenean populations were included, the mean value was 0.23. Among the 378 pairwise $F_{\mathrm{ST}}$ comparisons tested, only 30 did not reveal any significant genetic differentiation (after permutation tests and Bonferroni correction; data not shown). This lack of differentiation concerned mainly the comparisons between hatchery strains and the comparisons involving sample 2 (five individuals).

Most comparisons between Mediterranean and Atlantic populations gave high and significant $F_{\mathrm{ST}}$ values. Among Atlantic river populations, the differentiation appeared high, especially between samples showing strong differences in $\mathrm{LDH}-\mathrm{C}^{*} 100$ frequencies.

Correspondence analysis (CA): The results of the CA are given in Figure 2, which presents the plane defined by the first two axes of the analysis. Only a few populations are plotted, as it was not possible to simply and clearly show all the populations analysed. The chosen samples were representative of the main groups identified with this technique. The positive part of the first axis clustered individuals belonging to the 90-group, with a superposition of rivers (sample 19 for example) and hatchery samples (24). On the negative side, two groups were present, separated along the second axis. The Atlantic individuals of the 100group were distributed over the negative part of axis 2 (ie sample 3), and the Mediterranean populations (sample 1 and the Spanish strain from the Cauteret hatchery, no. 22) were found on the positive part of this axis. Between these three clusters, composite populations occupied variable areas (for example sample 9). Nevertheless, there was no clear discontinuity among the main genetic types with several mixed populations between them. The alleles responsible for the separation along axis 1 were mainly: $\mathrm{ADH}^{*} 50$, $\mathrm{TF}^{*} 80, \mathrm{LDH}-\mathrm{C} 1^{*} 115, \mathrm{MDH}-3^{*} 110$ (for the negative values) and $\mathrm{MDH}-2 * 75$; $\mathrm{LDH}-\mathrm{C}^{*}{ }^{*} 100$ (for the positive ones). Along axis 2 , there was $\mathrm{CK}-\mathrm{A} 1{ }^{*} 125$ for the negative values and $\mathrm{ADH}^{*} 50, \mathrm{IDH}-3^{*} 127$ and $\mathrm{TF}^{*} 102$ for the positive ones.

Axis 3 did not show any clear tendency; hatchery samples seemed to be slightly separated from 90-group river samples (not shown).

Assignment tests: Results of the assignment tests are presented in Table 3. Each line indicates for the corresponding population the percentages of individuals that were assigned to the different samples. The percentages of individuals assigned to the sample where they were caught varied from $87 \%$ (for sample 14) to $7 \%$ (sample 21: a Mediterranean river with possible stocking). In comparisons among samples with the lowest LDH-C1*90 frequencies (populations 2 to 5), most individuals from 
Table 2 Microsatellite data : number of alleles $(A)$, unbiased expected $\left(\mathrm{H}_{\mathrm{nb}}\right)$ and observed $\left(\mathrm{H}_{\mathrm{o}}\right)$ heterozygosity, and $F_{\mathrm{IS}}$ for each locus and each sample. At the bottom, multilocus $F_{\mathrm{IS}}$ estimates, and significance: $P$ gives the percentage of values greater than or equal to the observed value among 1000 permutations.

\begin{tabular}{|c|c|c|c|c|c|c|c|c|c|c|c|c|c|}
\hline $\begin{array}{l}\text { Sample } \\
\text { No. }\end{array}$ & & $\begin{array}{l}2 \\
5\end{array}$ & $\begin{array}{l}3 \\
24\end{array}$ & $\begin{array}{r}4 \\
30\end{array}$ & $\begin{array}{r}5 \\
29\end{array}$ & $\begin{array}{r}6 \\
25\end{array}$ & $\begin{array}{r}9 \\
15\end{array}$ & $\begin{array}{l}16 \\
86\end{array}$ & $\begin{array}{l}17 \\
86\end{array}$ & $\begin{array}{l}19 \\
88\end{array}$ & $\begin{array}{l}24 \\
50\end{array}$ & $\begin{array}{l}25 \\
30\end{array}$ & $\begin{array}{l}26 \\
36\end{array}$ \\
\hline Strutta 58 & $\begin{array}{l}\mathrm{A} \\
\mathrm{H}_{\mathrm{nb}} \\
\mathrm{H}_{\mathrm{o}} \\
F_{\mathrm{IS}}\end{array}$ & $\begin{array}{l}2 \\
0.20 \\
0.20 \\
0\end{array}$ & $\begin{array}{l}11 \\
0.85 \\
0.46 \\
0.47\end{array}$ & $\begin{array}{l}11 \\
0.74 \\
0.25 \\
0.66\end{array}$ & $\begin{array}{l}14 \\
0.89 \\
0.48 \\
0.46\end{array}$ & $\begin{array}{l}15 \\
0.86 \\
0.68 \\
0.22\end{array}$ & $\begin{array}{l}13 \\
0.91 \\
0.60 \\
0.35\end{array}$ & $\begin{array}{l}19 \\
0.84 \\
0.60 \\
0.29\end{array}$ & $\begin{array}{l}15 \\
0.91 \\
0.73 \\
0.20\end{array}$ & $\begin{array}{l}13 \\
0.78 \\
0.55 \\
0.29\end{array}$ & $\begin{array}{r}14 \\
0.89 \\
0.92 \\
-0.04\end{array}$ & $\begin{array}{l}14 \\
0.91 \\
0.90 \\
0.01\end{array}$ & $\begin{array}{l}20 \\
0.91 \\
0.91 \\
0.01\end{array}$ \\
\hline MST73 & $\begin{array}{l}\mathrm{A} \\
\mathrm{H}_{\mathrm{nb}} \\
\mathrm{H}_{\mathrm{o}} \\
F_{\mathrm{IS}}\end{array}$ & $\begin{array}{l}3 \\
0.51 \\
0.20 \\
0.64\end{array}$ & $\begin{array}{l}5 \\
0.50 \\
0.33 \\
0.34\end{array}$ & $\begin{array}{l}5 \\
0.68 \\
0.22 \\
0.68\end{array}$ & 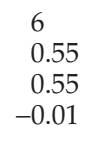 & $\begin{array}{l}5 \\
0.55 \\
0.36 \\
0.35\end{array}$ & $\begin{array}{l}4 \\
0.68 \\
0.60 \\
0.13\end{array}$ & $\begin{array}{l}3 \\
0.30 \\
0.25 \\
0.15\end{array}$ & $\begin{array}{l}5 \\
0.64 \\
0.59 \\
0.08\end{array}$ & $\begin{array}{l}5 \\
0.40 \\
0.34 \\
0.16\end{array}$ & $\begin{array}{l}4 \\
0.69 \\
0.63 \\
0.09\end{array}$ & $\begin{array}{l}3 \\
0.53 \\
0.24 \\
0.55\end{array}$ & $\begin{array}{l}5 \\
0.55 \\
0.44 \\
0.21\end{array}$ \\
\hline MST15 & $\begin{array}{l}\mathrm{A} \\
\mathrm{H}_{\mathrm{nb}} \\
\mathrm{H}_{\mathrm{o}} \\
F_{\mathrm{IS}}\end{array}$ & $\begin{array}{l}2 \\
0.20 \\
0.20 \\
0\end{array}$ & $\begin{array}{l}5 \\
0.46 \\
0.46 \\
0\end{array}$ & \begin{tabular}{l}
\multicolumn{1}{l}{5} \\
0.54 \\
0.64 \\
-0.19
\end{tabular} & $\begin{array}{l}3 \\
0.31 \\
0.36 \\
-0.14\end{array}$ & $\begin{array}{l}4 \\
0.66 \\
0.52 \\
0.22\end{array}$ & \begin{tabular}{l}
6 \\
\multicolumn{1}{l}{0.77} \\
0.80 \\
-0.03
\end{tabular} & $\begin{array}{l}5 \\
0.61 \\
0.51 \\
0.16\end{array}$ & $\begin{array}{l}5 \\
0.71 \\
0.71 \\
0.01\end{array}$ & $\begin{array}{l}6 \\
0.26 \\
0.23 \\
0.13\end{array}$ & 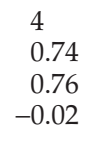 & $\begin{array}{l}4 \\
0.68 \\
0.79 \\
-0.17\end{array}$ & $\begin{array}{l}5 \\
0.68 \\
0.63 \\
0.08\end{array}$ \\
\hline Ssa197 & $\begin{array}{l}\mathrm{A} \\
\mathrm{H}_{\mathrm{nb}} \\
\mathrm{H}_{\mathrm{o}} \\
F_{\mathrm{IS}}\end{array}$ & $\begin{array}{l}3 \\
0.51 \\
0.60 \\
-0.20\end{array}$ & $\begin{array}{l}10 \\
0.88 \\
0.88 \\
0\end{array}$ & $\begin{array}{l}10 \\
0.82 \\
0.75 \\
0.08\end{array}$ & $\begin{array}{l}9 \\
0.80 \\
0.61 \\
0.25\end{array}$ & $\begin{array}{l}9 \\
0.80 \\
0.88 \\
-0.11\end{array}$ & $\begin{array}{l}7 \\
0.73 \\
0.93 \\
-0.29\end{array}$ & $\begin{array}{l}8 \\
0.77 \\
0.73 \\
0.06\end{array}$ & $\begin{array}{l}10 \\
0.81 \\
0.81 \\
0\end{array}$ & $\begin{array}{l}6 \\
0.77 \\
0.81 \\
-0.05\end{array}$ & $\begin{array}{l}6 \\
0.78 \\
0.84 \\
-0.08\end{array}$ & $\begin{array}{l}5 \\
0.81 \\
0.79 \\
0.02\end{array}$ & $\begin{array}{l}7 \\
0.82 \\
0.81 \\
0\end{array}$ \\
\hline Ssa171 & $\begin{array}{l}\mathrm{A} \\
\mathrm{H}_{\mathrm{nb}} \\
\mathrm{H}_{\mathrm{o}} \\
F_{\mathrm{IS}}\end{array}$ & $\begin{array}{l}5 \\
0.82 \\
1 \\
-0.25\end{array}$ & $\begin{array}{l}5 \\
0.49 \\
0.42 \\
0.16\end{array}$ & $\begin{array}{l}8 \\
0.84 \\
0.63 \\
0.25\end{array}$ & $\begin{array}{l}9 \\
0.79 \\
0.40 \\
0.50\end{array}$ & $\begin{array}{l}7 \\
0.77 \\
0.48 \\
0.38\end{array}$ & $\begin{array}{l}8 \\
0.87 \\
0.33 \\
0.63\end{array}$ & $\begin{array}{l}14 \\
0.84 \\
0.78 \\
0.07\end{array}$ & $\begin{array}{l}11 \\
0.83 \\
0.76 \\
0.09\end{array}$ & $\begin{array}{l}17 \\
0.89 \\
0.56 \\
0.37\end{array}$ & $\begin{array}{l}11 \\
0.84 \\
0.56 \\
0.34\end{array}$ & $\begin{array}{l}13 \\
0.86 \\
0.72 \\
0.16\end{array}$ & $\begin{array}{l}12 \\
0.79 \\
0.63 \\
0.21\end{array}$ \\
\hline MST543 & $\begin{array}{l}\mathrm{A} \\
\mathrm{H}_{\mathrm{nb}} \\
\mathrm{H}_{\mathrm{o}} \\
F_{\mathrm{IS}}\end{array}$ & $\begin{array}{l}4 \\
0.80 \\
0.80 \\
0\end{array}$ & $\begin{array}{l}6 \\
0.62 \\
0.43 \\
0.31\end{array}$ & $\begin{array}{l}6 \\
0.64 \\
0.68 \\
-0.06\end{array}$ & $\begin{array}{l}7 \\
0.51 \\
0.45 \\
0.11\end{array}$ & $\begin{array}{l}2 \\
1 \\
1 \\
-\end{array}$ & $\begin{array}{l}7 \\
0.82 \\
0.46 \\
0.44\end{array}$ & $\begin{array}{l}12 \\
0.83 \\
0.71 \\
0.14\end{array}$ & $\begin{array}{l}11 \\
0.76 \\
0.60 \\
0.21\end{array}$ & $\begin{array}{l}7 \\
0.65 \\
0.58 \\
0.11\end{array}$ & $\begin{array}{l}8 \\
0.78 \\
0.66 \\
0.16\end{array}$ & $\begin{array}{l}8 \\
0.82 \\
0.79 \\
0.03\end{array}$ & $\begin{array}{l}10 \\
0.77 \\
0.75 \\
0.02\end{array}$ \\
\hline $\begin{array}{l}\text { mean } \mathrm{A} \\
\text { mean } \mathrm{H}_{\mathrm{nb}} \\
\text { mean } \mathrm{H}_{\mathrm{o}}\end{array}$ & & $\begin{array}{l}3.2 \\
0.51 \\
0.50\end{array}$ & $\begin{array}{l}7 \\
0.63 \\
0.50\end{array}$ & $\begin{array}{l}7.5 \\
0.71 \\
0.53\end{array}$ & $\begin{array}{l}8 \\
0.64 \\
0.47\end{array}$ & $\begin{array}{l}7 \\
0.77 \\
0.65\end{array}$ & $\begin{array}{l}7.5 \\
0.80 \\
0.62\end{array}$ & $\begin{array}{l}10.2 \\
0.70 \\
0.60\end{array}$ & $\begin{array}{l}9.5 \\
0.78 \\
0.70\end{array}$ & $\begin{array}{l}9 \\
0.62 \\
0.51\end{array}$ & $\begin{array}{l}7.8 \\
0.79 \\
0.73\end{array}$ & $\begin{array}{l}7.8 \\
0.77 \\
0.71\end{array}$ & $\begin{array}{l}9.8 \\
0.75 \\
0.70\end{array}$ \\
\hline $\begin{array}{l}F_{\text {IS }} \\
\% \geq\end{array}$ & & $\begin{array}{l}0.02 \\
52.2 \\
\text { NS }\end{array}$ & $\begin{array}{l}0.22 \\
0^{*}\end{array}$ & $\begin{array}{l}0.26 \\
0^{*}\end{array}$ & $\begin{array}{l}0.26 \\
0^{*}\end{array}$ & $\begin{array}{l}0.16 \\
0^{*}\end{array}$ & $\begin{array}{l}0.23 \\
0^{*}\end{array}$ & $\begin{array}{l}0.14 \\
0^{*}\end{array}$ & $\begin{array}{l}0.10 \\
0^{*}\end{array}$ & $\begin{array}{l}0.18 \\
0^{*}\end{array}$ & $\begin{array}{l}0.08 \\
0.2^{*}\end{array}$ & $\begin{array}{l}0.08 \\
2.1^{*}\end{array}$ & $\begin{array}{l}0.08 \\
1.1^{*}\end{array}$ \\
\hline
\end{tabular}

*Significant after a Bonferroni correction; $\mathrm{k}=12 . \mathrm{NS}=$ not significant; - = missing data. Population names: see Table 1.

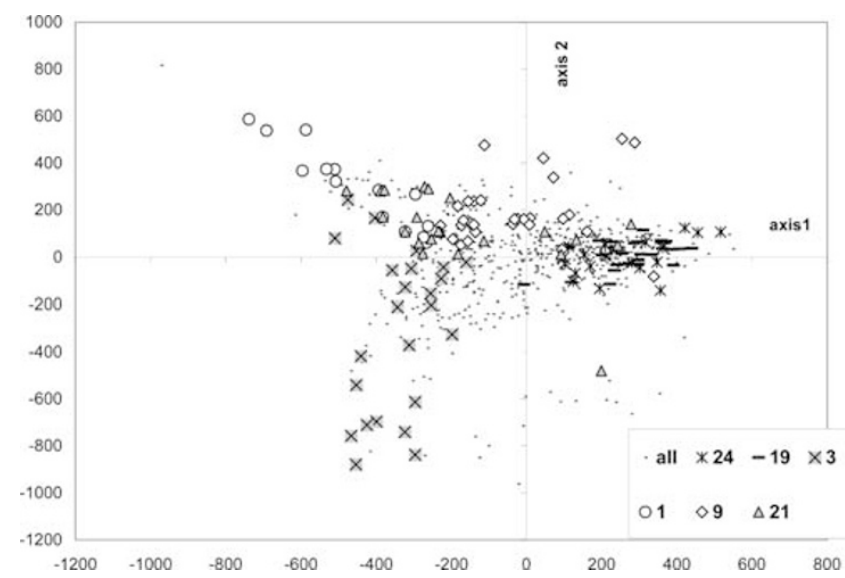

Figure 2 Allozyme data. Correspondence analysis (all samples included): projection of the individuals on the plane defined by the first two axes. Rare alleles were not included in the analysis (see text for details). Inertia: axis 1: $4.7 \%$, axis $2: 4.1 \%$. these populations were assigned to this group or to the Cauteret Mediterranean hatchery strain (23). Among samples 16 to 20 (LDH-C1*90 frequency varying from 0.82 to 0.96$)$, most individuals were also classified into this group or inside populations with a lower but still high frequency of this allele. Only one individual found in one of these two groups was classified in the other group. Concerning the assignations to hatchery strains, apart from the Mediterranean strain 22 (see Discussion), the percentages of possible domestic individuals in river samples (according to this method) varied from 0 to $27 \%$ (for sample 11).

\section{Microsatellites}

Choice of the samples to be analysed: As the distinction between Atlantic and Mediterranean populations is now well established using allozymes (Guyomard, 1989), mitochondrial DNA (Bernartchez et al, 1992; Poteaux et al, 1998b) and microsatellites (Poteaux et al, 1999), we first focused on the distinction between the two presumed 
Table 3 Allozyme data - assignment tests: percentages of individuals of each population assigned to the different samples according to their probability of appearance in these samples. Each individual was assigned to the sample where it presented the highest probability. Each line represents for one population, the assignment of its individuals among the different samples. For example line 1 indicates that for population 1, 36\% of the individuals were effectively assigned to population 1, 0 to population 2 . Bold numbers indicate the highest percentages for each sample. The first square indicates comparisons among river samples with the lowest LDH-C1*90 frequencies, the second, river samples with the highest LDH-C1*90, and the third one, comparisons among hatchery samples.

\begin{tabular}{|c|c|c|c|c|c|c|c|c|c|c|c|c|c|c|c|c|c|c|c|c|c|c|c|c|c|c|c|}
\hline & 1 & 2 & 3 & 4 & 5 & 6 & 7 & 8 & 9 & 10 & 11 & 12 & 13 & 14 & 15 & 16 & 17 & 18 & 19 & 20 & 21 & 22 & 23 & 24 & 25 & 26 & 27 \\
\hline 1 & 36 & 0 & 0 & 0 & 0 & 0 & 0 & 0 & 0 & 0 & 0 & 23 & 0 & 0 & 0 & 0 & 0 & 0 & 0 & 0 & 0 & 41 & 0 & 0 & 0 & 0 & 0 \\
\hline 2 & 0 & 60 & 0 & 0 & 0 & 0 & 0 & 0 & 0 & 0 & 0 & 0 & 0 & 0 & 0 & 0 & 0 & 0 & 0 & 0 & 0 & 40 & 0 & 0 & 0 & 0 & 0 \\
\hline 3 & 0 & 21 & 42 & 29 & 4 & 0 & 0 & 0 & 0 & 0 & 0 & 0 & 0 & 0 & 0 & 0 & 0 & 0 & 0 & 0 & 0 & 4 & 0 & 0 & 0 & 0 & 0 \\
\hline 4 & 3 & 17 & 13 & 47 & 10 & 0 & 0 & 0 & 0 & 0 & 0 & 0 & 0 & 0 & 0 & 0 & 0 & 0 & 0 & 0 & 0 & 10 & 0 & 0 & 0 & 0 & 0 \\
\hline 5 & 0 & 10 & 0 & 24 & 34 & 14 & 0 & 0 & 0 & 0 & 0 & 0 & 10 & 3 & 0 & 0 & 0 & 0 & 0 & 0 & 0 & 3 & 0 & 0 & 0 & 0 & 0 \\
\hline 6 & 0 & 3 & 3 & 0 & 20 & 17 & 17 & 3 & 3 & 3 & 0 & 0 & 3 & 3 & 0 & 3 & 3 & 0 & 0 & 0 & 0 & 13 & 0 & 0 & 0 & 3 & 0 \\
\hline 7 & 0 & 0 & 0 & 7 & 3 & 27 & 23 & 0 & 0 & 7 & 3 & 0 & 0 & 0 & 3 & 0 & 3 & 3 & 3 & 0 & 10 & 3 & 0 & 3 & 0 & 0 & 0 \\
\hline 8 & 0 & 0 & 0 & 7 & 3 & 3 & 7 & 27 & 3 & 3 & 3 & 3 & 7 & 0 & 7 & 0 & 3 & 3 & 3 & 0 & 3 & 10 & 3 & 0 & 0 & 0 & 0 \\
\hline 9 & 0 & 0 & 0 & 0 & 0 & 0 & 3 & 0 & 67 & 3 & 7 & 7 & 0 & 0 & 0 & 0 & 0 & 0 & 0 & 0 & 7 & 0 & 3 & 0 & 0 & 0 & 3 \\
\hline 10 & 0 & 0 & 5 & 0 & 0 & 0 & 0 & 0 & 0 & 32 & 23 & 0 & 5 & 0 & 5 & 0 & 0 & 9 & 0 & 0 & 9 & 9 & 0 & 0 & 0 & 0 & 5 \\
\hline 11 & 0 & 0 & 0 & 0 & 0 & 0 & 3 & 3 & 6 & 18 & 18 & 6 & 0 & 0 & 3 & 0 & 0 & 6 & 3 & 3 & 6 & 0 & 15 & 0 & 9 & 3 & 0 \\
\hline 12 & 3 & 0 & 0 & 3 & 0 & 0 & 0 & 0 & 13 & 0 & 0 & 37 & 0 & 0 & 0 & 0 & 0 & 3 & 3 & 0 & 17 & 20 & 0 & 0 & 0 & 0 & 0 \\
\hline 13 & 0 & 3 & 0 & 0 & 10 & 3 & 0 & 7 & 3 & 3 & 0 & 0 & 33 & 0 & 7 & 10 & 0 & 0 & 3 & 7 & 0 & 7 & 0 & 0 & 0 & 0 & 3 \\
\hline 14 & 0 & 0 & 0 & 3 & 0 & 0 & 3 & 0 & 0 & 0 & 0 & 0 & 3 & 87 & 0 & 0 & 3 & 0 & 0 & 0 & 0 & 0 & 0 & 0 & 0 & 0 & 0 \\
\hline 15 & 0 & 0 & 0 & 0 & 0 & 0 & 0 & 0 & 0 & 3 & 0 & 3 & 0 & 0 & 57 & 3 & 0 & 7 & 3 & 3 & 10 & 7 & 3 & 0 & 0 & 0 & 0 \\
\hline 16 & 0 & 0 & 3 & 0 & 0 & 0 & 0 & 0 & 3 & 3 & 3 & 0 & 3 & 0 & 7 & 23 & 3 & 7 & 3 & 13 & 0 & 0 & 20 & 0 & 0 & 3 & 3 \\
\hline 17 & 0 & 0 & 0 & 0 & 0 & 0 & 0 & 3 & 0 & 0 & 3 & 3 & 0 & 0 & 10 & 3 & 37 & 0 & 7 & 20 & 0 & 0 & 3 & 3 & 3 & 0 & 3 \\
\hline 18 & 0 & 0 & 0 & 0 & 0 & 0 & 0 & 7 & 3 & 0 & 0 & 0 & 3 & 0 & 7 & 7 & 0 & 60 & 3 & 3 & 3 & 0 & 3 & 0 & 0 & 0 & 0 \\
\hline 19 & 0 & 0 & 0 & 0 & 0 & 0 & 0 & 3 & 0 & 0 & 0 & 0 & 0 & 0 & 7 & 0 & 3 & 0 & 60 & 13 & 0 & 0 & 7 & 0 & 0 & 7 & 0 \\
\hline 20 & 0 & 0 & 0 & 0 & 0 & 0 & 0 & 0 & 0 & 0 & 0 & 0 & 3 & 0 & 7 & 10 & 3 & 0 & 20 & 43 & 0 & 0 & 13 & 0 & 0 & 0 & 0 \\
\hline 21 & 0 & 0 & 0 & 0 & 0 & 0 & 0 & 0 & 0 & 0 & 0 & 0 & 0 & 0 & 3 & 0 & 3 & 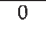 & 3 & 0 & 7 & 73 & 7 & 0 & 0 & 0 & 3 \\
\hline 22 & 5 & 0 & 0 & 0 & 0 & 0 & 0 & 0 & 0 & 0 & 0 & 0 & 0 & 0 & 0 & 0 & 0 & 0 & 0 & 0 & 25 & 70 & 0 & 0 & 0 & 0 & 0 \\
\hline 23 & 0 & 0 & 0 & 0 & 0 & 0 & 4 & 0 & 0 & 0 & 0 & 0 & 0 & 0 & 4 & 0 & 8 & 0 & 0 & 0 & 0 & 4 & 52 & 8 & 20 & 0 & 0 \\
\hline 24 & 0 & 0 & 0 & 0 & 0 & 0 & 0 & 0 & 3 & 0 & 0 & 0 & 0 & 0 & 3 & 0 & 0 & 0 & 0 & 31 & 0 & 0 & 3 & 41 & 6 & 0 & 13 \\
\hline 25 & 0 & 0 & 0 & 0 & 0 & 0 & 0 & 0 & 0 & 0 & 3 & 0 & 0 & 0 & 0 & 0 & 0 & 0 & 0 & 13 & 0 & 0 & 40 & 23 & 20 & 0 & 0 \\
\hline 26 & 0 & 0 & 0 & 0 & 0 & 0 & 6 & 0 & 0 & 0 & 6 & 0 & 0 & 0 & 6 & 3 & 3 & 25 & 3 & 3 & 0 & 0 & 14 & 0 & 8 & 14 & 11 \\
\hline 27 & 0 & 0 & 0 & 0 & 0 & 0 & 0 & 0 & 0 & 0 & 7 & 0 & 0 & 10 & 3 & 0 & 0 & 0 & 3 & 3 & 0 & 0 & 23 & 17 & 0 & 0 & 33 \\
\hline
\end{tabular}

Atlantic population groups. Secondly, because allozymes did not separate wild and domestic trout from the 90group, microsatellites were also used for this task. These considerations led to the selection of samples for the microsatellite investigation given in Table 1.

Genetic variability within populations: This variability can be biased by small sample size, so the results concerning sample 2, with only five individuals, should be analysed cautiously.

The observed and expected heterozygosity, the number of alleles, and the $F_{\mathrm{IS}}$ values and their significance are given in Table 2. It should be noted that among river populations the observed number of alleles was slightly higher for samples 16, 17 and 19 that had the highest sample sizes. The most variable populations in terms of their mean $\mathrm{H}_{\mathrm{nb}}$ were the three hatchery strains and some river populations such as samples 6 and 9 (which seemed, from allozymes, to be mixed) and 17, with $\mathrm{H}_{\mathrm{nb}}$ between 0.75 and 0.80 . High and significant heterozygote deficiencies were observed in all samples (except UNT). This was attributable mainly to three loci, which showed strong disequilibria: Strutta 58, MST73 and Ssa171.

For linkage disequilibria, 192 tests were performed, and after a sequential Bonferroni correction, three remained significant and all concerned population 16 . They indicated linkage disequilibria between the loci Strutta 58 and Ssa197, Strutta 58 and Ssa171, Ssa 197 and Ssa171 with $R$ values of $0.11,0.13$ and 0.11 respectively.

Genetic differences among populations: The allelic distributions did not show any diagnostic microsatellite locus distinguishing between populations from the 90 and 100- groups, nor between the domestic and river samples. Nevertheless, a few private alleles were detected, especially for the 100-group populations that had some alleles not observed elsewhere, but which shared many other alleles with the 90-group. This prevented the direct use of allelic frequency for computing an introgression index for domestic fish in rivers (like the one developed by Poteaux et al, 1999).

The $F_{\mathrm{ST}}$ values were generally high and always significant even after a Bonferroni correction (data not shown). The lowest $F_{\mathrm{ST}}$ values were observed between hatchery strains, and the highest ones between the ' 90 ' and '100' group populations. The mean $F_{\mathrm{ST}}$ value among all comparisons was 0.15 .

CA on microsatellites: The results of the CA are given in Figures 3 and 4. Rare alleles (which were present less than four times in the overall data set) were removed because they introduced too much distortion. On the graph, population 9 was specially highlighted because of its strong domestic influence, as indicated by a preliminary genetic analysis using Artificial Neural Networks results (Aurelle et al, 1999) and as confirmed by the fish morphology (JM Lascaux, personal communication).

The first two axes of the analysis including all populations (Figure 3) clearly separated the 90-group (including hatcheries) from the 100-group, with a limited zone of overlap between them (although this analysis was only conducted using microsatellite loci). This separation was mainly due to axis 1 , which was the most informative (inertia: 4.7\%). Sample nine individuals were distributed between the two groups, which confirms the heterogeneous composition of this sample. River popu- 


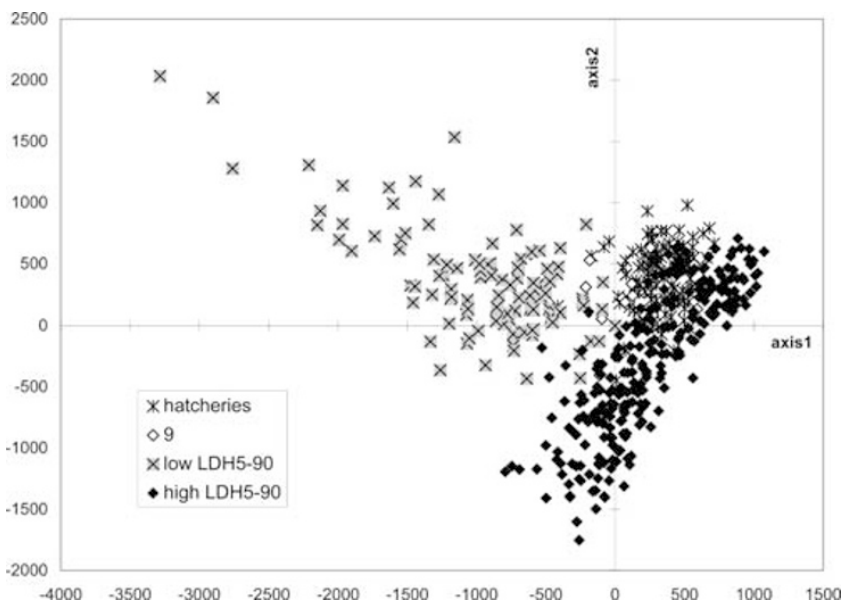

Figure 3 Microsatellite data. Correspondence analysis of a part of the populations belonging to the I and II groups: projection of the individuals on the plane defined by the first two axes. Rare alleles were not included in the analysis (see text for details). Inertia: axis 1: $4.7 \%$, axis $2: 4.1 \%$.

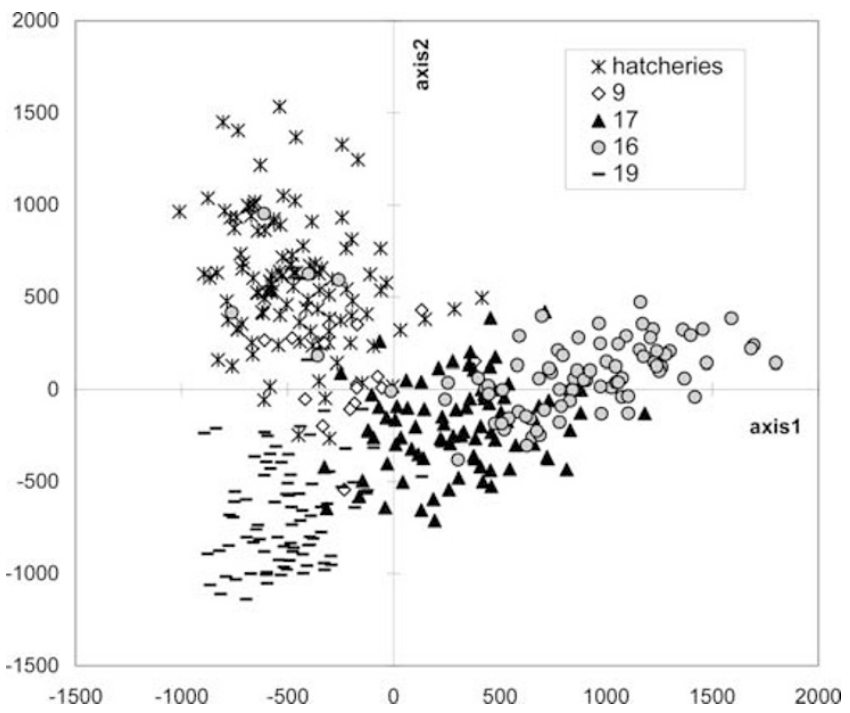

Figure 4 Microsatellite data. Correspondence analysis conducted hatcheries and rivers populations with high $\mathrm{LDH}-\mathrm{C} 1{ }^{*} 90$ frequencies. ADO5, for which a stocking influence was suspected, was also included in the analysis. Rare alleles were not included in the analysis (see text for details). Inertia: Axis 1: $6.3 \%$, axis 2: $5.2 \%$.

lations from the 90-group were grouped together with hatcheries. The separation between domestic and wild fish inside this lineage was not clear, probably because the main discrimination of this CA (90 vs 100) hides the other ones.

Another CA conducted only on group 90 (Figure 4) indicated a clear separation between hatcheries (top left) and river fish from populations 16, 17 and 19, which appeared to be mainly wild, whereas sample 9 showed a mixed distribution. Moreover this last analysis showed subdivisions between the different wild samples with two polarities: population 16 (positive values on axis 1) and 19 (negative values); 17 appeared to be intermediate between the two forms.
Table 4 Microsatellite data - assignment tests: percentages of individuals of each population assigned to the different samples according to their probability of appearance in these samples. Each individual was assigned to the sample where it presented the highest probability. Each line represents for one population, the assignment of its individuals among the different samples (see methods and Table 3 for more details).

\begin{tabular}{|c|c|c|c|c|c|c|c|c|c|c|c|c|}
\hline & 2 & 3 & 4 & 5 & 6 & 9 & 16 & 17 & 19 & 24 & 25 & 26 \\
\hline 2 & 100 & 0 & 0 & 0 & 0 & 0 & 0 & 0 & 0 & 0 & 0 & 0 \\
\hline 3 & 0 & 79 & 17 & 0 & 0 & 0 & 0 & 0 & 4 & 0 & 0 & 0 \\
\hline 4 & 0 & 10 & 80 & 0 & 0 & 3 & 0 & 0 & 0 & 7 & 0 & 0 \\
\hline 5 & 0 & 3 & 0 & 86 & 7 & 3 & 0 & 0 & 0 & 0 & 0 & 0 \\
\hline 6 & 0 & 0 & 0 & 8 & 76 & 8 & 4 & 0 & 0 & 0 & 0 & 4 \\
\hline 9 & 0 & 0 & 0 & 0 & 7 & 60 & 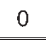 & 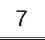 & 7 & 13 & 7 & 0 \\
\hline 16 & 0 & 0 & 0 & 1 & 0 & 0 & 81 & 12 & 0 & 1 & 1 & 3 \\
\hline 17 & 0 & 1 & 0 & 0 & 0 & 3 & 7 & 85 & 2 & 1 & 0 & 0 \\
\hline 19 & 0 & 0 & 0 & 0 & 0 & 0 & 0 & 1 & 93 & 1 & 1 & 3 \\
\hline 24 & 0 & 0 & 0 & 0 & 0 & 0 & 0 & 0 & 0 & 82 & 6 & 12 \\
\hline 25 & 0 & 3 & 0 & 0 & 0 & 3 & 0 & 0 & 0 & 3 & 73 & 17 \\
\hline 26 & 0 & 0 & 0 & 0 & 0 & 0 & 0 & 0 & 0 & 25 & 14 & 61 \\
\hline
\end{tabular}

Assignment tests: The results of the assignment test conducted with microsatellite loci are given in Table 4 . The percentages of individuals assigned to the sample where they were found varied from 93 (for sample 19; 100\% for the small sample 2) to $60 \%$ (sample 9). These percentages were much higher than those obtained with allozymes for the same samples. Concerning the distinction between the two population groups, very few individuals from one group were assigned to the other one. Only two individuals ( $7 \%$ of sample 4 ) from populations with high LDH-C ${ }^{*} 100$ frequencies were assigned to hatcheries. For the 90-group river populations, the proportions of possible domestic individuals varied from 1 to $5 \%$. Population 9 (mixed) appeared to have the highest percentage of supposed domestic fish: $20 \%$.

\section{Discussion}

\section{Heterozygote deficiencies}

The high and generalised heterozygote deficiencies observed in our data, and especially for microsatellite loci, can have several origins. Allozymes also showed some heterozygote deficiencies, but not for all populations. As we tried to sample fish of various sizes, we probably did not analyse many related individuals, which could create such problems (Hansen et al, 1997).

This could be caused by a Wahlund effect created by sampling several genetically differentiated forms present in this area: domestic fish and two kinds of wild fish (from the 90 or 100 population groups). Concerning the presence of domestic fish, stocked populations often present such deficits as observed in the Mediterranean basin (Largiadèr and Scholl, 1996; Poteaux and Berrebi, 1997; Poteaux et al, 1999), and here in samples 21 and 9. Such deficits have also been observed in apparently unstocked populations (populations with high LDH-C1* 100 frequency such as samples 2 or 3). They could be explained by the presence of wild individuals from the two population groups (only one individual from sample 3 was assigned to the other group) in the same basin if 
the contact is recent or if there is a substantial reproductive isolation. Nevertheless, we have no biological indication of any reproductive isolation. No linkage disequilibria were observed as expected in the case of a Wahlund effect (Waples and Smouse, 1990), apart from samples 9 and 21 where we suspect a stocking influence.

Linkage disequilibria in microsatellites are probably more difficult to reveal due to the high number of alleles, and the Bonferroni correction could have hidden some weak disequilibria (for example in the sample 17, four locus pairs appeared at first to have a significant linkage disequilibrium at the $5 \%$ level, but none remained after the Bonferroni correction). The presence of some null alleles for some microsatellite loci could also explain the higher number of significant heterozygote deficiencies observed with these markers when compared to allozymes.

\section{Assignment tests}

As further discussions will rely on assignment tests, we should first analyse their efficiency. Generally, allozymes gave higher percentages of misassignments than do microsatellites. This confirms that, as already mentioned, microsatellites might be more powerful for discriminating populations showing low levels of differentiation. However, in the assignment using allozymes, some loci were not used because of missing data. This was the case for the TF locus which is important for discriminating between Mediterranean and Atlantic samples (especially the 100-group). This could explain the high observed percentages of individuals from the 100-group assigned to the Mediterranean hatchery strain 22.

\section{Evaluation of stocking impact using microsatellites}

In order to interpret the observed genetic differences and to separate natural and artificial effects in population structuring, we first evaluated the stocking impact using microsatellites. These evaluations were based on three samples from hatcheries that provide eggs and fish to local managers in the studied area. CA, using both allozymes and microsatellites, has shown the relative homogeneity of domestic samples (except the Spanish strain 22 and a few individuals from 26). Assignment tests confirmed these results, with quite high proportions of misassignments among these samples. This allowed us to consider the three domestic samples analysed with microsatellites as being representative of those used for stocking throughout France, given that previous studies had already shown the homogeneity of domestic strains (Guyomard, 1989). Nevertheless, the presence of Mediterranean alleles $\left(\mathrm{TF}^{*} 102\right)$ in several samples is probably the result of the rare and unusual stocking with Mediterranean trout, which sometimes takes place.

Allozyme loci tend to show 100-group populations as not being affected by stocking (domestic strains are almost fixed for LDH-C $1 * 90)$. Nevertheless, artificial neural networks (ANN; applied to four of the microsatellite loci used here and only to a subset of populations) have shown that sample $5(96 \%$ of LDH-C1*100) could have a modern (possibly domestic) influence (Aurelle et al, 1999). This was confirmed by mitochondrial DNA analysis (Aurelle and Berrebi, 2001) but not by assignment tests. This could be the result of different nuclear and mitochondrial introgression rates, as have already been observed in the Mediterranean basin (Poteaux et al, 1998b). The mixed populations 6 and 9 (with both $L D H$ -
$C 1^{*}$ alleles) are apparently introgressed by domestic alleles, and this phenomenon is particularly powerful for sample 9. This agrees well with morphological observations (domestic individuals can be visually distinguished from wild ones, JM Lascaux, personal communication), with genetic disequilibria observed using allozymes, and with CA and assignment tests. The microsatellite data give an estimate of $20 \%$ of domestic individuals in this population. For river samples 16, 17 and 19 with high LDH-C1*90 frequencies, ANN showed that there has been very limited stocking (Aurelle et al, 1999; Giraudel et al, 2000), and only a few individuals are likely to be descended from the domestic type. This was also consistent with assignment tests using more microsatellite loci.

We can conclude that with few exceptions, river samples analysed with microsatellites were not strongly modified by stocking, which is a favourable situation for the study of natural differentiation.

These results also indicate that stocked fish did not become established in most rivers. However, even if the immediate impact of stocking appears low, repeated introductions can modify the genetic composition of natural populations and this can potentially create several genetic risks (reviewed in Leary et al, 1995).

\section{Differentiated lineages in the western Pyrenees}

Allelic frequencies at a few diagnostic allozyme loci allowed us to define several levels of structuring of the groups of populations, which were then confirmed by statistical analyses and more precisely defined by microsatellite data. The highest observed differentiation occurs between Atlantic and Mediterranean populations. Atlantic populations are characterised mainly by the $\mathrm{TF}^{*}$ 100 allele and Mediterranean ones by the 102 allele. Nevertheless, the 102 allele was also present in several Atlantic populations. This could be the sign of an ancestral polymorphism, which has not been observed elsewhere in the Atlantic basin (Guyomard, 1989; Poteaux et al, 1998a). Nevertheless, TF frequencies are not known for all Atlantic populations. For example, Spanish populations which exhibit high $\mathrm{LDH}-\mathrm{C} 1^{*} 100$ frequencies have not been analysed for the TF locus.

The existence of natural contact between Mediterranean and Atlantic populations following river-capture (see for example Guyomard, 1989) is less probable because of the topography of this part of the Pyrenees.

Among the populations from the Atlantic basin, some were fixed or almost fixed for LDH-C1*90 and the others for $\mathrm{LDH}-\mathrm{C} 1^{*} 100$. This distinction was confirmed by the CA results (Figure 2), and the assignment tests with few misassignments among the most characteristic populations (Table 3). Moreover, this distinction was independently confirmed using microsatellites: the first axis of the CA conducted with these markers (Figure 3) also clearly separated these two groups, as did the assignment tests (Table 4). Finally an analysis of the variability of mitochondrial control region has shown, for the first time, that the different types were characterised by different dominant haplotypes (Aurelle and Berrebi, 2001). It is not easy to evaluate the proportions of these two lineages in the different populations as, apart from the $\mathrm{LDH}$ $C 1^{*}$ alleles, no diagnostic alleles are available. Nevertheless, assignment tests using microsatellites seem efficient for such study and could give an estimation of the hom- 
ogeneity of these samples. Our results based on nine river populations clearly indicate that few exchanges took place among the most divergent populations (populations 2-6 compared with populations 16-19). These are also among the most geographically distant populations. The 90-group is well represented in the eastern part of the Adour basin, whereas the 100-group is mainly located in the western part and in small isolated basins. Despite the absence of major natural barriers (apart from the fact that habitats are not suitable for brown trout in the lower part of the Adour), gene flow among these two groups appears to be low (as confirmed by $F_{\mathrm{ST}}$ values), and must have taken place among populations from the same areas and more or less directly connected by the water system. This would be consistent with the presence of mixed populations between these two groups. As already mentioned, we did not find any evidence any reproductive isolation, thus the migration rate must be the important factor explaining this situation. Some anadromous trout can be found in the Adour basin, but they apparently have not modified this structure.

How can we relate these groups to the main lineages defined in other studies? The hypothesis of an ancestral and a modern form proposed by Hamilton et al (1989) does not apply here for several reasons. First, south-western France was ice-free during the last glacial events. Secondly the distribution of the different lineages does not fit with a scenario where a modern form replaces an ancestral one.

Do these two groups then correspond to the lineages I and II as defined by Garcia-Marin et al (1999)? These authors also based their distinction on $C K-A 1^{*}$ alleles: CK-A1*115 (synonymous to the 125 allele according to Ferguson (2000) being fixed in lineage II. This was apparently not the case here as some populations with high levels of $\mathrm{LDH}-\mathrm{C} 1^{*} 100$ did not possess the CK-A1*125 allele (population 5 for example). Conversely some populations with high levels of LDH-C1*90 had the CK-A1* 125 allele (sample 17 and two hatchery strains). It is then difficult to assign the populations studied here to one of the lineages defined by Garcia-Marin et al (1999). Moreover, new data provided by Weiss et al (2000) would indicate that post-glacial dispersal of brown trout was much more geographically limited than previously assumed. Our analysis of the mitochondrial control region (Aurelle and Berrebi, 2001) and the results of Bernatchez (2001) also suggested that the $\mathrm{LDH}-\mathrm{C} 1 * 90$ populations analysed in this area were probably not derived from a northern European refuge as proposed by Garcia-Marin et al (2000).

The genetic diversity of the 90-group populations would indicate that this area could have been a possible glacial refuge. According to Bernatchez (2001), southern populations would also have contributed to the recolonisation of northern Europe along with other Atlantic lineages. The 100-group populations could have originated from the south (the LDH-C1*100 predominates in Spain) and would have come into secondary contact with the 90-group established there before the last glaciations.

This hypothesis of a secondary contact agrees with the results of Bernatchez (2001) who proposed, using a nested clade analysis, that mtDNA variability in southern France and Spain could be explained by a past fragmentation. Concerning the date of this event, Bernatchez
(2001) proposed that the most important demographic expansion of the AT lineage could have taken place 13 400 to 26800 years ago, corresponding to the last glacial event, but this would have to be tested more precisely with our samples.

From a conservation point of view, some of the populations analysed here are genetically distinct and should be protected, especially against stocking. They constitute an important source of genetic diversity. Some local fishery managers are already trying to act in this way.

\section{Conclusion}

The patterns of genetic differentiation of French western Pyrenees populations clearly show the existence of two forms of Atlantic brown trout. Despite the existence of mixed populations, some pure populations are still present. This could indicate that gene flow has not been sufficient to lead to a homogenisation of these two forms.

This situation provides, at a local scale, new insights for evaluating the validity of the different hypotheses concerning the evolutionary history of this species in the Atlantic basin. It seems probable that this history was marked by several independent events of recolonisation and secondary contacts.

\section{Acknowledgements}

Sampling campaigns were made thanks to the help of the staff of the Ecole Nationale Supérieure d'Agronomie de Toulouse and researchers and students of the Laboratoire Génome et Populations. The allozymic data for the Brassac and Canourgue samples were kindly provided by $C$ Poteaux. Useful morphological information was provided by JM Lascaux from ENSAT. The authors gratefully acknowledge D Hedgecock and F Bonhomme for their help in improving an earlier stage of the manuscript. This study was supported by grants from the EC (EV5VCT920097), the Association TFP, the Club Halieutique, the CSP and the BRG.

\section{References}

Aurelle D, Berrebi P (1998). Microsatellite markers and management of brown trout Salmo trutta fario populations in southwestern France. Genet Sel Evol 30: S75-S90.

Aurelle D, Berrebi P (2001). Genetic structure of brown trout (Salmo trutta, L.) populations from south-western France: data from mitochondrial control region variability. Mol Ecol 10: 1551-1562.

Aurelle D, Lek S, Berrebi P, Giraudel JL (1999). Microsatellites and artificial neural network: tools to discriminate natural and hatcheries brown trout (Salmo trutta, L.) in Atlantic populations. Ecol Model 120: 313-324.

Beaudou D (1993). Impact des déversements de truites domestiques dans les populations naturelles de truites communes (Salmo trutta fario). Etude dynamique et génétique. Cas du bassin de l'Orb (Hérault). Thesis University Montpellier II (France).

Belkhir K, Borsa P, Goudet J, Chikhi L, Bonhomme F (1998). GENETIX, logiciel sous WindowsTM pour la génétique des populations. Freely available at: http://www.univmontp2.fr/ genetix/genetix.htm. Laboratoire Génome et Populations, CNRS UPR 9060, Université Montpellier II, Montpellier (France).

Bernatchez L (2001). The evolutionary history of brown trout (Salmo trutta L.) inferred from phylogeographic, nested clade, 
and mismatch analyses of mitochondrial DNA variation. Evolution 55: 351-379.

Bernatchez L, Dodson JJ (1991). Phylogeographic structure in mitochondrial DNA of the lake whitefish (Coregonus clupeaformis) and its relation to Pleistocene glaciations. Evolution 45: 1016-1035

Bernatchez L, Guyomard R, Bonhomme F (1992). DNA sequence variation of the mitochondrial control region among geographically and morphologically remote European brown trout Salmo trutta populations. Mol Ecol 1: 161-173.

Bernatchez L, Wilson CC (1998). Comparative phylogeography of Nearctic and Palearctic fishes. Mol Ecol 7: 431-452

Berrebi P, Poteaux C, Fissier M, Cattaneo-Berrebi G (2000). Stocking impact and allozyme diversity in brown trout from Mediterranean southern France. I Fish Biol 56: 949-960.

Black WC, Krafsur ES (1985). A FORTRAN program for the calculation and analysis of two-locus linkage disequilibrium coefficients. Theor Appl Genet 70: 491-496.

Dowling TE, Hoeh WR (1991). The extent of introgression outside the contact zone between Notropis cornutus and N. chrysocephalus (Teleostei: Cyprinidae). Evolution 45: 944-956

Durand JD, Persat H, Bouvet Y (1999). Phylogeography and post glacial dispersion of the Chub (Leuciscus cephalus) in Europe. Mol Ecol 8: 989-997

Estoup A, Rousset F, Michalakis Y, Cornuet JM, Adriamanga M, Guyomard R (1998). Comparative analysis of microsatellite and allozyme markers: a case study investigating microgeographic differentiation in brown trout (Salmo trutta). Mol Ecol 7: 339-353.

Ferguson A (2000). Polymorphic loci in brown trout and agreed nomenclature of alleles. In: Consolidated final report of the concerted action on identification, management and exploitation of genetic resources in brown trout, Salmo trutta, FAIR CT97-3882. pp 23-31.

Ferguson A, Fleming CC (1983). Evolutionary and taxonomic significance of protein variation in brown trout (Salmo trutta fario) and other salmonid fishes. In: Oxford G, Rollinson D (eds) Protein Polymorphism: Adaptative and Taxonomic Significance vol. 24. Academic Press: London and New York, pp 85-99.

Ferguson A, Taggart JB, Prodöhl PA, MacMeel O, Thompson C, Stone C, MacGinnity P, Hynes RA (1995). The application of molecular markers to the study and conservation of fish populations with special reference to Salmo. J Fish Biol 47 (Suppl): 103-126.

Garcia-Marin J-L, Utter FM, Pla C (1999). Postglacial colonization of brown trout in Europe based on distribution of allozyme variants. Heredity 82: 46-56.

Giraudel JL, Aurelle D, Lek S, Berrebi P (2000). Application of the self-organizing mapping and fuzzy clustering to microsatellite data: how to detect genetic structure in brown trout (Salmo trutta) populations. In: Lek S, Guégan JF (eds) Artificial Neuronal Networks. Springer-Verlag: Berlin, pp 87-202.

Guinand B (1996). Use of a multivariate model using allele frequency distribution to analyse patterns of genetic differentiation among populations. Biol J Linn Soc 58: 173-195.

Guyomard R (1989). Diversité génétique de la truite commune. Bull Fr Pêche Pisc 314: 118-135.

Hamilton KE, Ferguson A, Taggart JB, Tomasson T, Walker A, Fahy E (1989). Post-glacial colonisation of brown trout, Salmo trutta L.: Ldh-5 as a phylogeographic marker locus. J Fish Biol 35: 651-664.

Hansen MM, Hynes RA, Loeschcke V, Rasmussen G (1995). Assessment of the stocked or wild origin of anadromous brown trout (Salmo trutta L.) in a Danish river system, using mitochondrial DNA RFLP analysis. Mol Ecol 4: 189-198.

Hansen MM, Neilsen EE, Mensberg K-LD (1997). The problem of sampling families rather than populations: relatedness among individuals in samples of juvenile brown trout Salmo trutta L. Mol Ecol 6: 469-474.

Hewitt GM (1996). Some genetic consequences of ice ages, and their role in divergence and speciation. Biol J Linn Soc 58: 247-276.

Hynes RA, Ferguson A, McCann MA (1996). Variation in mitochondrial DNA and post-glacial colonization of north western Europe by brown trout. J Fish Biol 48: 54-67.

Jarne P, Lagoda PJL (1996). Microsatellites, from molecules to populations and back. TREE 11: 424-428.

Krieg F (1984). Recherche d'une différenciation génétique entre populations de Salmo trutta. Thesis University Paris-Sud, Orsay (France).

Largiadèr CR, Scholl A (1996). Genetic introgression between native and introduced brown trout (Salmo trutta L.) populations in the Rhone River Basin. Mol Ecol 5: 417-426.

Leary RF, Allendorf FW, Sage GK (1995). Hybridization and introgression between introduced and native fish. Am Fisheries Soc Symp 15: 91-101.

Mandrak NE, Crossman EJ (1992). Postglacial dispersal of freshwater fishes into Ontario. Can J Zool 70: 2247-2259

O'Reilly PT, Hamilton LC, McConnell SK, Wright JM (1996). Rapid analysis of genetic variation in Atlantic salmon (Salmo salar) by PCR multiplexing of dinucleotids and tetranucleotids microsatellites. Can J Fish Aquat Sci 53: 2292-2298.

Pasteur N, Pasteur G, Bonhomme F, Catalan J, Britton-Davidian J (1987). Manuel de génétique par électrophorèse des protéines. Lavoisier: Paris.

Persat H, Berrebi P (1990). Relative ages of present populations of Barbus barbus and Barbus meridionalis (Cyprinidae) in southern France: preliminary considerations. Aquat Living Res 3: 253-263

Poteaux C, Berrebi P (1997). Intégrité génomique et repeuplements chez la truite commune du versant méditerranéen. Bull Fr Pêche Piscic 344/345: 309-322.

Poteaux C, Beaudou D, Berrebi P (1998a). Temporal variations of genetic introgression in stocked brown trout (Salmo trutta L.) populations. J Fish Biol 53: 701-713.

Poteaux C, Bonhomme F, Berrebi P (1998b). Differences between nuclear and mitochondrial introgressions of brown trout populations from a restocked main river and its unrestocked tributary. Biol J Linn Soc 63: 379-392.

Poteaux C, Bonhomme F, Berrebi P (1999). Microsatellite polymorphism and genetic impact of restocking in Mediterranean brown trout (Salmo trutta L.). Heredity 82: 645-653.

Presa P, Krieg F, Estoup A, Guyomard R (1994). Diversité et gestion génétique de la truite commune: apport de l'étude du polymorphisme des locus protéiques et microsatellites. Genet Sel Evol 26 (Suppl 1): 183-202.

Rice WR (1989). Analyzing tables of statistical tests. Evolution 43: 223-225.

Sanchez JA, Clabby B, Ramos D, Blanco G, Flavin F, Vazquez E, Powell R (1996). Protein and microsatellite single locus variability in Salmo salar L. (Atlantic salmon). Heredity 77: 423-432.

Taberlet P, Fumagalli L, Wust-Saucy A-G, Cosson J-F (1998). Comparative phylogeography and postglacial colonization routes in Europe. Mol Ecol 7: 453-464.

Waples RS, Smouse PE (1990). Gametic disequilibrium analysis as a means of identifying mixtures of salmon populations. Am Fisheries Soc Symp 7: 439-458.

Weir BS, Cockerham CC (1984). Estimating F-statistics for the analysis of population structure. Evolution 38: 1358-1370.

Weiss S, Antunes A, Schlötterer C, Alexandrino P (2000). Mitochondrial haplotype diversity among Portuguese brown trout Salmo trutta L. populations: relevance to the post-Pleistocene recolonization of northern Europe. Mol Ecol 9: 691-698. 


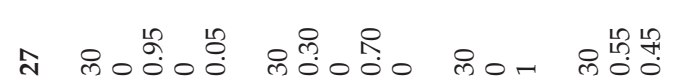

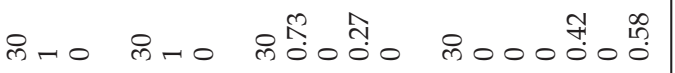

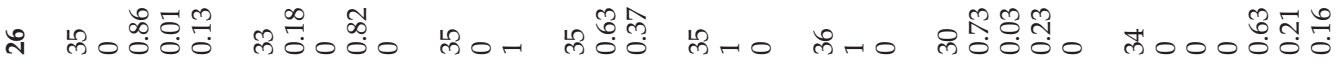

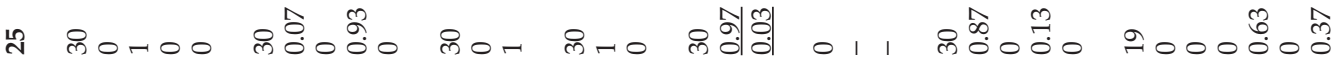

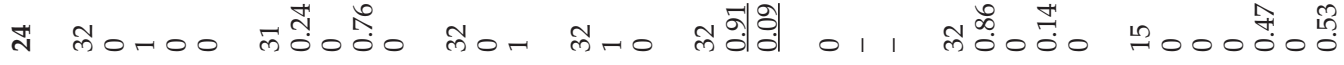

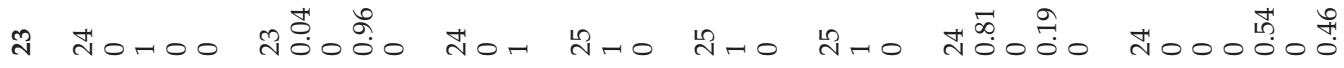

ก

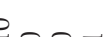

a

$\infty$

$\stackrel{\infty}{\sim}-0 \stackrel{\infty}{\sim}-0$

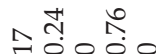

$2000-00$

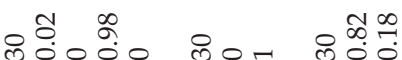

î-0 iे-0

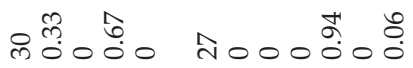

noroo

तิ கా

moon

으

in-

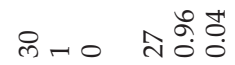

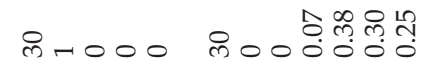

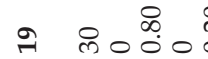

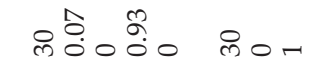

in-o

मेन० हे-0

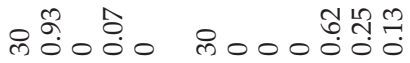

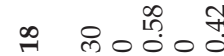

mooro हo-

क्ष-0

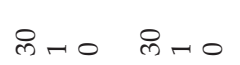

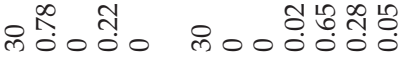

त० $\stackrel{0}{0} 0 \stackrel{m}{0}$

กั

(요

के $\rightarrow$

क्रम० तेन०

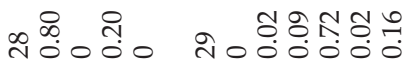

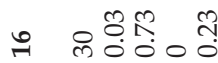

กิ กั

ते०-

مº

into $e_{-0}$

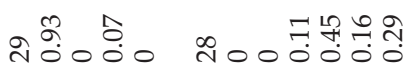

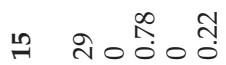

ते००ण ते०

ळे-0

हेन० मेन०

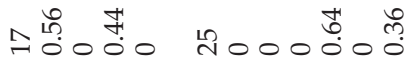

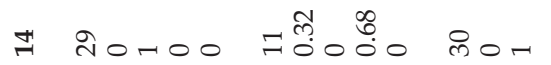

(n)

0 -

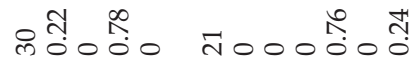

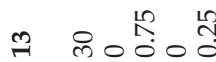

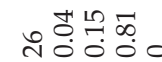

के०-

0 -

in-0

ํํำ

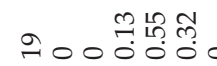

व क्र०० के

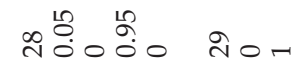

iे -0

in-0 o

สกิ ฉ

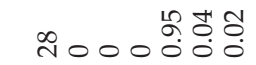

F mo

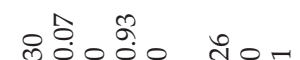

$+\infty$

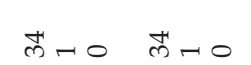

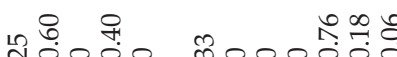

(1)

ก ำ ำ

ก

งิูกิร

4-

ㄴํำ 虽

000

व

ลิ०

in-

into हिन0

舲

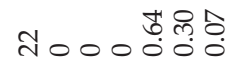

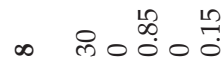

त $m$

(8)

两

हि-0 हि-0

- mo:

iั

요

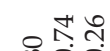

into

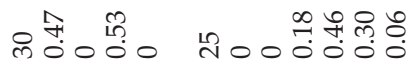

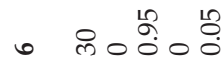

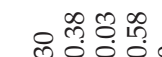

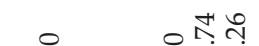

0 - 0

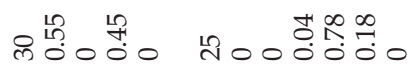

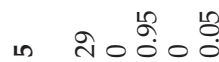

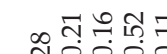

ino

(itso

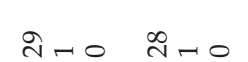

年 గิ

ํํำ

-

용

R

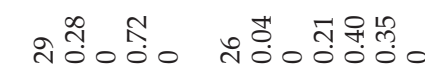

$\infty$

N no-00 +o $\overbrace{0}^{\infty} 0_{0}^{\infty}$

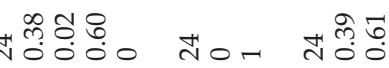

A-

रิ तึํํำ

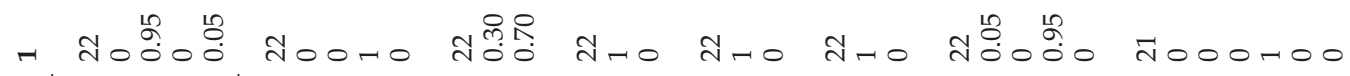




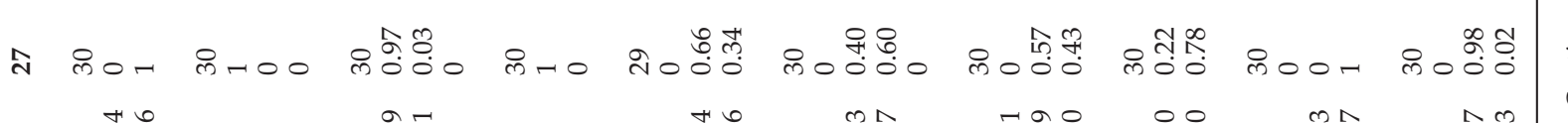

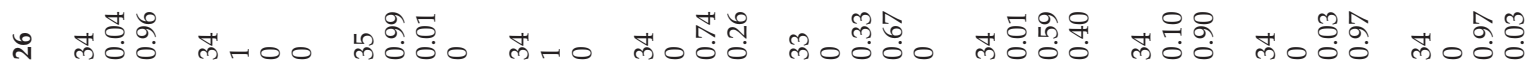

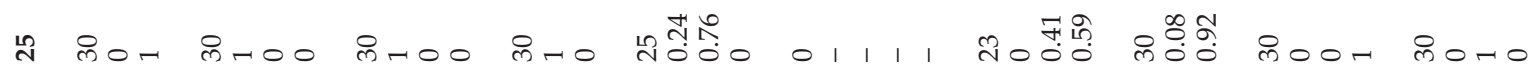

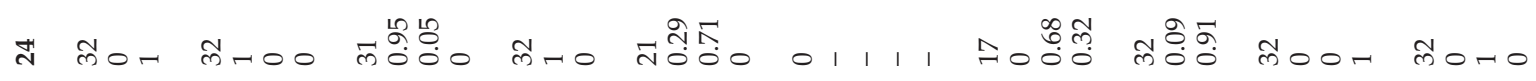

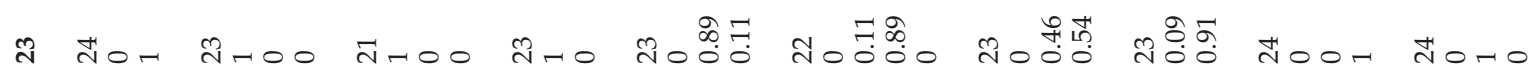

ส

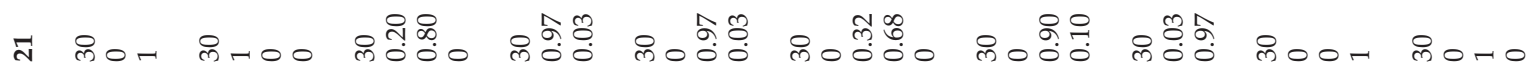

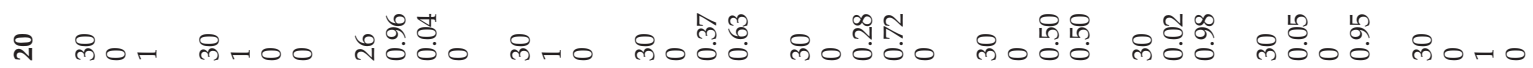

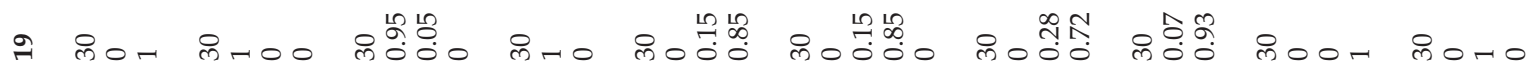

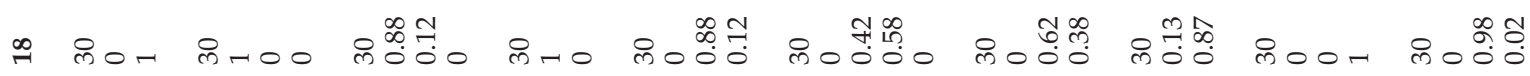

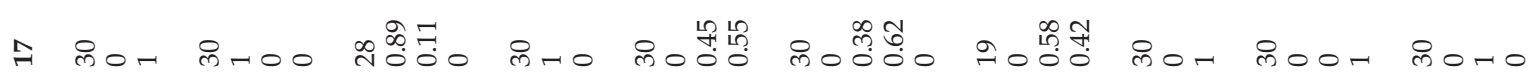

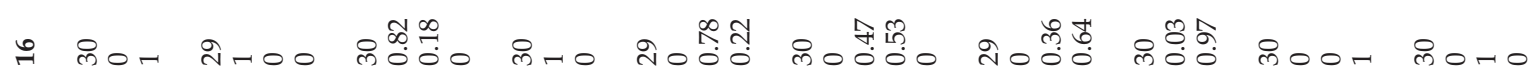

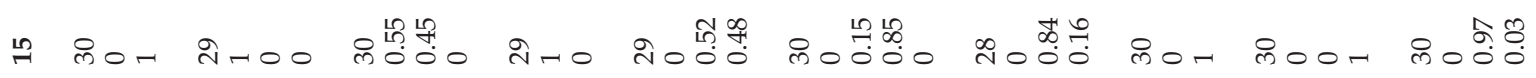

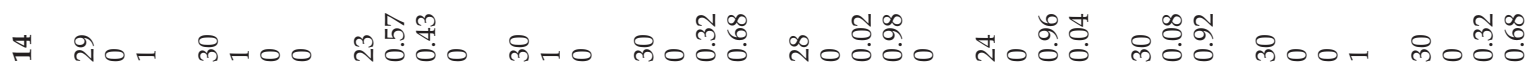

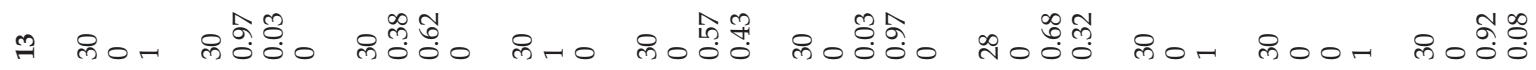

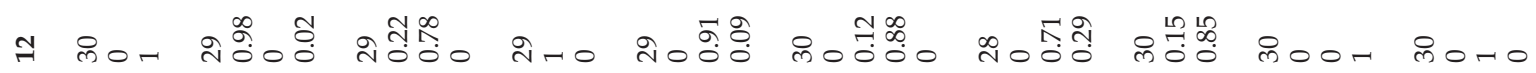

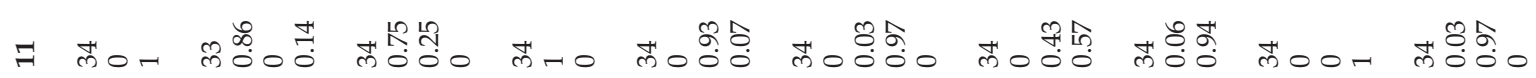

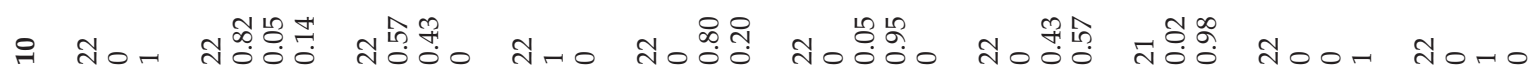

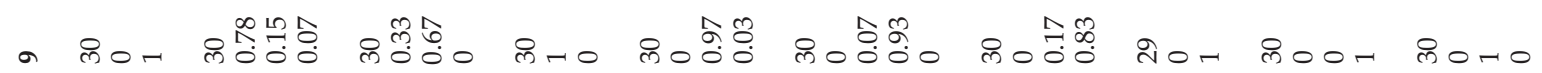

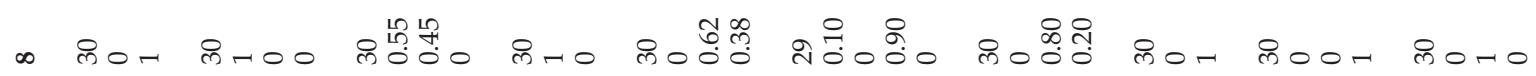

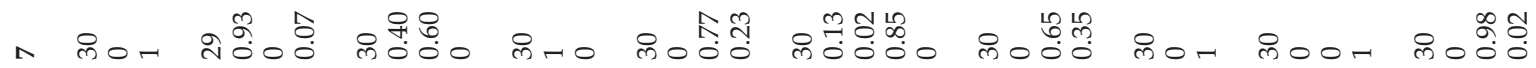

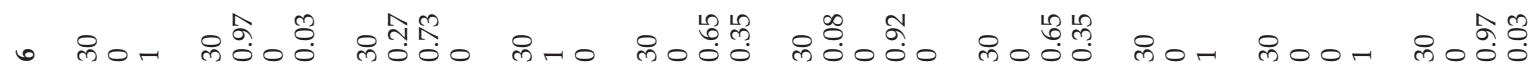

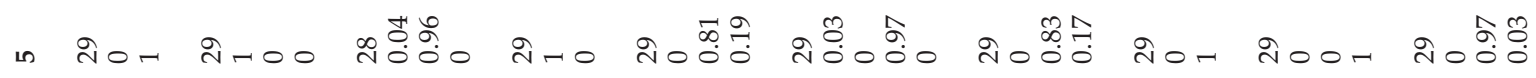

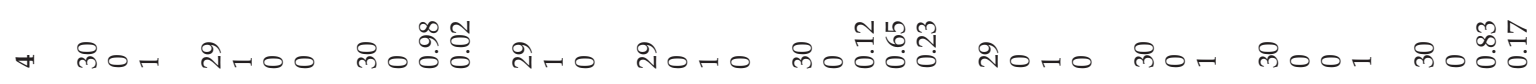

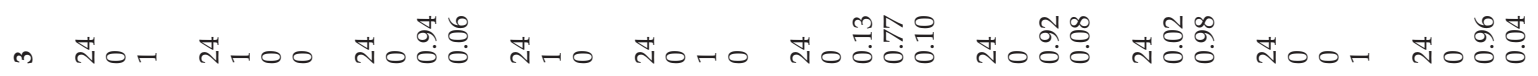

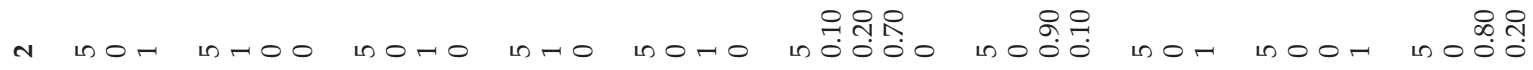

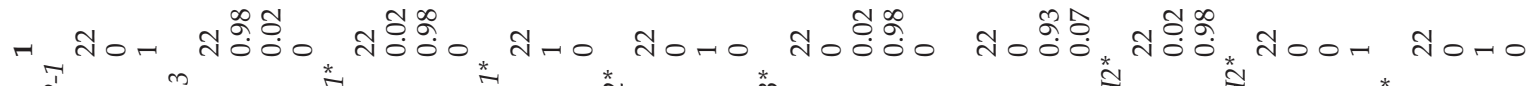

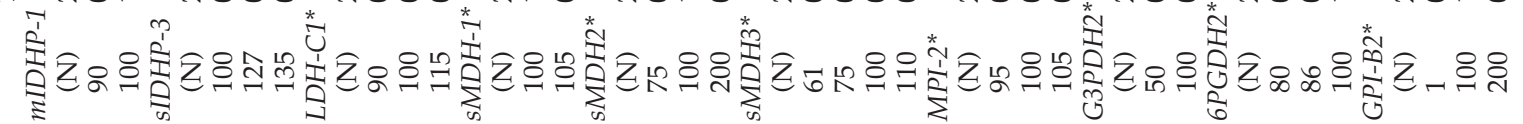




\begin{tabular}{|c|c|c|c|c|c|}
\hline ลิ & চ $\stackrel{\infty}{0} \stackrel{0}{0}$ & ले०o- & கింo-0 & 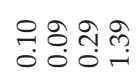 & そ̋ \\
\hline ని & ॠ & ట゙ంoro & 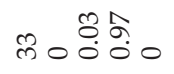 & 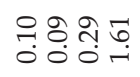 & 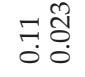 \\
\hline$\stackrel{2}{4}$ & ది-000 & pిooro & pిooro & 등 훙 స్요 & î́ \\
\hline ম & है-0 00 & ñooro & के००-0 & \& & î́ \\
\hline$\approx$ & $\Delta-000$ & Nooro & L $00-0$ & : & î́ \\
\hline ส & $\infty \stackrel{0}{\circ} \stackrel{0}{0} 0$ & $\stackrel{\infty}{\rightarrow} \circ \circ-0$ & 융용요 & 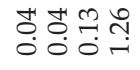 & 50 \\
\hline ส & लి-000 & ले०o-0 & స̃ $000 \stackrel{?}{\circ}$ & 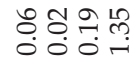 & కั \\
\hline สิ & nి-000 & लింoro & pిooro & 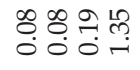 & io \\
\hline 2 & চ $\stackrel{\infty}{0} 00 \stackrel{\overbrace{}}{0}$ & கি০০-০ & LిOO-O & ڤộ & 00 \\
\hline$\stackrel{\infty}{\sim}$ & Dি- 000 & लింo- & సे०oro & 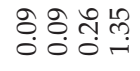 & : \\
\hline$\approx$ & लి-000 & సે & 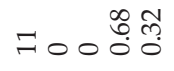 & ت: & 50 \\
\hline$\stackrel{2}{\sim}$ & लి-000 & 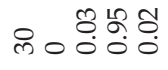 & 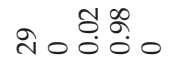 & 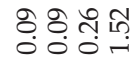 & î́ \\
\hline$\stackrel{2}{2}$ & लి-000 & के०ం-o & הิ০O-O & 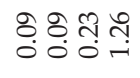 & Oீं \\
\hline 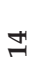 & कि-0 00 & கింoro & సे०o-0 & 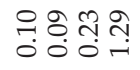 & 00 \\
\hline 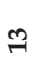 & हి- & கি০০ & Bিo o̊̊ & 궁중 중 & 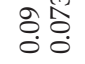 \\
\hline$\approx$ & लి-0 00 & கे০o-০ & 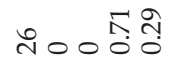 & ڤ్ & $\begin{array}{l}m \\
0 \\
0 \\
0\end{array}$ \\
\hline$\exists$ & હ゙ー000 & "ేంorం & 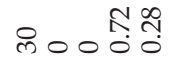 & 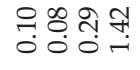 & 00 \\
\hline$?$ & $\tilde{A}-000$ & สิooro & 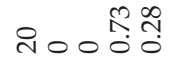 & 궁유 뀽 ్ㅠㅇ & $0^{\circ}$ \\
\hline$a$ & लि-000 & கింo-0 & 011111 & & त్ \\
\hline$\infty$ & ले-0 00 & 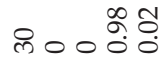 & เి & 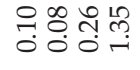 & 30 \\
\hline$n$ & nి-000 & 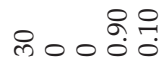 & L & 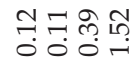 & 잉 \\
\hline 0 & लि-000 & 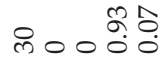 & 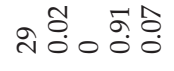 & 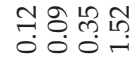 & ลิ * \\
\hline in & बे-0 00 & 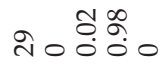 & సิo & 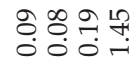 & $\begin{array}{ll}70 \\
0\end{array}$ \\
\hline r & लि-000 & க) o- & लेo & 不 & $\vec{m}$ \\
\hline m & $\vec{N}-000$ & ȦoOro & 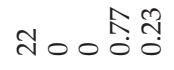 & 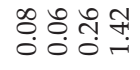 & กุ \\
\hline$N$ & $n \rightarrow 000$ & L $00-0$ & L $00-0$ & 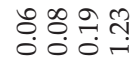 & i \\
\hline & 40 & Nooro & ๑ & 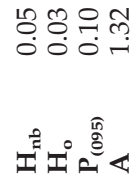 & 今 \\
\hline
\end{tabular}

